\title{
Antigens of a Human Breast Carcinoma Cell Line (BT 20). I. Synthesis of Serum Proteins, Membrane-Associated Antigens, and Oncofetal-Associated Antigens 1,2
}

\author{
J. Hurlimann ${ }^{3,4}$ and R. Dayal ${ }^{3,5}$
}

\begin{abstract}
The synthesis of various products by a human mammary cell line (BT 20) was studied by incorporation of ${ }^{14} \mathrm{C}$ labeled amino acids, choline, glucosamine, or galactosamine into nondialyzable materials. These products had molecular weights ranging trom less than 12,300 daltons to more than 200,000 daltons. They were analyzed by immunoelectrophoresis and double diffusion in agar. Among the synthesized products, the following proteins were identified: $\beta_{2}$-glycoprotein l, $\alpha_{2} \mathrm{HS}$-glycoprotein, $\alpha_{2}$-lipoprotein, actin, $\beta_{2}$-microglobulin, carcinoembryonic antigen, three oncofetal-associated antigens, and various erythrocyte membrane-associated antigens (namely, glycophorin). Synthesis of milk proteins was not detectable. Only the protein molety of the glycophorin molecule seemed to be synthesized. The $\beta_{2}$-microglobulin was synthesized in an unbound state as well as bound to a glycoprotein whose relationship with the transplantation or tumor antigens must be determined. The three oncofetal-associated antigens were also synthesized in vitro by human fetal tissues and neoplastic and dysplastic human mammary tissues.-J Natl Cancer Inst 61: 677-686, 1978.
\end{abstract}

Tumor-associated antigens are present on breast carcinoma cells. The evidence supporting the existence of such antigens is based largely on the demonstration of lymphocytes and antibodies against carcinoma cells and carcinoma extracts in patients with breasi carcinoma (1-7). Extracts from breast carcinoma and from a breast carcinoma cell line (MCF-7) have also been shown to inhibit the migration of leukocytes from patients with breast carcinoma $(8-10)$. Several attempts have been made to purify the tumor-associated antigens, but the results have been too different to allow any comparison (11-16). Essentially, these diverse results can be explained by the heterogeneity of the starting material and the difficulty in the solubilization of membrane-associated antigens. However, investigators have shown that several proteins are released in the culture fluids or can be isolated from cells of various tumor cell lines from human or animal origin and that some of these proteins are tumor-associated antigens $(17-22)$.

Isolation of various products synthesized by breast carcinoma cell lines could be important, inasmuch as these products might be used as carcinoma markers. Also, the purification of breast carcinoma tumorassociated antigens released in the culture fluids by these cell lines would be useful for immunodiagnosis and production of specific antisera.

In this study, we have attempted to analyze the products synthesized by a human mammary cell line (BT 20) for two reasons: 1) The starting material consisted only of tumor cells and was constant and reproducible; 2) several products released in the culture fluids of this cell line were soluble, therefore making it unnecessary to use solubilization techniques which are difficult and denaturing. We selected the BT 20 cell line because it seemed to have kept the properties of a breast carcinoma. These cells have an ultrastructure similar to that of the original tumor (23). When transplanted into nude mice, they produce tumors morphologically similar to the original mammary carcinoma (24). They can be used as target cells in cytotoxicity tests (4).

We studied the synthesis of several products in this cell line by incorporation of labeled amino acids, choline, galactosamine, and glucosamine into nondialyzable materials. These products were analyzed by immunoelectrophoresis and double diffusion in agar with antisera against serum, milk, and membraneassociated and oncofetal-associated antigens.

\section{MATERIALS AND METHODS}

Antigens.-Human milk was obtained from the Department of Gynecology and Obstetrics, University of Lausanne. Free secretory component was prepared from human milk by the method of Brandtzaeg (25). Lactoferrin was isolated from human milk (26). Lactalbumin was purified according to the method of Kaplanas and Antanavichyns (27). The milk fraction rich in $\boldsymbol{\beta}_{2}$-microglobulin used as carrier for autoradiographs was isolated from milk. Human lactoserum was fractionated on a Sephadex G-200 column. The last fraction was chromatographed on a DEAE-cellulose column equilibrated with $0.01 \mathrm{M}(\mathrm{pH} 7.0)$ phosphate buffer. After the first protein peak had been obtained, the remaining proteins were eluted by a linear $\mathrm{NaCl}$ gradient in the starting buffer. The fractions rich in $\boldsymbol{\beta}_{2}$ -

Abrreviations uSED: BOFA $=\beta$-oncofetal antigen; $C E A=$ carcinoembryonic antigen; $F C S=$ fetal calf serum; $S D S=$ sodium dodecyl sulfate; $\mathrm{SP}=$ specific for pregnancy.

\footnotetext{
1 Received July 14, 1977; revised December 14, 1977; accepted March 17, 1978

2 Supported in part by a grant from the Swiss National Foundation for Scientific Research.

${ }^{3}$ Department of Pathology, University of Lausanne, Medical School, 1011 Lausanne, Switzerland; and Department of Pathology, Hôpital Cantonal Universitaire, CH-1011 Lausanne, Switzerland. ${ }_{4}$ Address reprint requests to Dr. Hurlimann at the Hopital Cantonal Universitaire.

${ }_{5}^{5}$ We thank Dr. L. Ozzello, Department of Pathology, University of Lausanne, for his advice and Mrs. Michèle Nicolet and Mrs. Simone Burki for their technical help.
} 
microglobulin were pooled. Acid-precipitated casein from human milk was chromatographed on a DEAEcellulose column by the method of Nagasawa et al. (28). Fraction 5 was used, which corresponds to a fraction of the $\beta$-casein group. Spectrin and glycophorin were gifts from Dr. C. Bron, Department of Biochemistry, University of Lausanne. CEA and BOFA were gifts from Dr. J. P. Mach, Department of Biochemistry, University of Lausanne. Actin was a gift from Dr. G. Gabbiani, Department of Pathology, University of Geneva, Geneva, Switzerland. Human placenta lactogen and $\beta_{1}$ SP-glycoprotein were obtained from Behringwerke, Marburg, Federal Republic of Germany. Human ferritin ( $\beta$-fetoprotein) and human serum negative for $\beta$-fetoprotein were obtained from Bioware Inc., Wichita, Kansas.

Antisera.-Antisera against free secretory component, lactoferrin, milk, casein, and lactalbumin were produced in rabbits weighing $2.5-3 \mathrm{~kg}$. The rabbits were immunized im each week with $500 \mu \mathrm{g}$ of protein in $\mathrm{l} \mathrm{ml}$ saline in emulsion with an equal part of Freund's complete adjuvant. They were bled 1 week after receiving the third injection.

To render them specific, the antisera were absorbed with various proteins from human milk and/or human serum. Each of these antisera was tested by immunoelectrophoresis and by double diffusion in agar against human serum and human milk. Antiserum against free secretory component gave one line against lactoserum with a cathodal spur corresponding to the bound secretory component. Antisera against lactalbumin, casein, and lactoferrin gave a single line against milk. The antimilk serum gave several lines against milk but no lines against human serum.

Antisera against BT 20 cells were obtained by immunization of rabbits with BT 20 cells cultured during 9 days without FCS and prepared as described later in "Tissue cultures" (sample 4). The immunization method was as described for milk proteins. The unabsorbed anti-BT 20 antisera did not reveal human milk or serum proteins nor did they reveal FCS proteins when tested by double diffusion in agar and by immunoelectrophoresis with various concentrations of human serum, human milk, and FCS.

Antisera against spectrin and glycophorin were gifts from Dr. C. Bron, Department of Biochemistry, University of Lausanne. Two antiglycophorin antisera were used. One of the antisera was obtained in a rabbit by immunization with glycophorin isolated according to the method of Tillack et al. (29). The other was obtained in a rabbit by immunization with a glycophorin fraction obtained upon electrophoresis of this protein in SDS polyacrylamide gel. The 2 antisera were absorbed with polymerized human plasma and blood groups A and B (30). Both antisera revealed only the glycophorin line in immunoelectrophoresis with red blood cell ghosts solubilized in Nonidet P-40. Although the first of these antisera perhaps contained antibodies against actin, spectrin, and band 3 of red blood cell ghosts electrophoresed in SDS-polyacrylamide gel, the second seemed to be specific for glyco- phorin (31). The antiserum specific for spectrin was obtained by immunization of rabbits with a spectrin fraction obtained by electrophoresis of red blood cell stroma in SDS-polyacrylamide 5\% gel. This antiserum was specific for spectrin as shown by two-dimensional immunoelectrophoresis with red blood cell stroma.

Antiserum against BOFA was a gift from Dr. J. P. Mach. It has been characterized by Fritsché and Mach (32). Serum from a patient with chronic aggressive hepatitis was used as an antiactin antiserum and was obtained from Dr. G. Gabbiani. The specificity of this antiserum for actin has been shown by immunofluorescence and immunodiffusion (33).

The following antisera were obtained commercially: swine antiserum polyvalent against human serum (Research Institute for Immunology, Prague, Czechoslovakia); rabbit antisera specific for $\alpha_{1}$-fetoprotein, $\beta_{1} \mathrm{SP}$ glycoprotein, placental lactogen, $\boldsymbol{\beta}_{2}$-glycoprotein I, $\alpha_{2}$ HS-glycoprotein, $\alpha_{1}$-lipoprotein, ceruloplasmin, transferrin, haptoglobin, hemopexin, $\alpha_{1}$-acid glycoprotein, $\boldsymbol{\beta}_{2}$-glycoprotein III, and $\boldsymbol{\beta}$-lipoprotein (Behringwerke, Marburg); rabbit antisera specific for erythrocyte membrane, $\beta_{2}$-microglobulin, and CEA (Dakopatts, Copenhagen, Denmark); and rabbit antiserum specific for ferritin (Bioware Inc.).

Tissue cultures.-The BT 20 cell line, originating from an infiltrating ductal breast carcinoma, was obtained from Dr. L. Ozzello. These cells were grown as monolayers in 25- $\mathrm{cm}^{2}$ plastic flasks (Falcon Plastics, Oxnard, Calif.) in medium RPMI-1640 supplemented with 2\% FCS (Gibco-Biocult, Glasgow, Scotland). The BT 20 cultures were controlled three times for mycoplasma during the study. They were mycoplasma-free at the beginning but were mycoplasma-positive after 1 year. New BT 20 cells free of mycoplasma were obtained for our study. The material used for our study was obtained from mycoplasma-free cultures as well as from contaminated cultures.

For incorporation studies, the cells, 24 hours after passage, were washed with Hanks' balanced salt solution without $\mathrm{Ca}^{2+}$ and $\mathrm{Mg}^{2^{+}}$(Gibco-Biocult) and cultured with $3 \mathrm{ml}$ of the adequate radioactive medium for 72 hours. Thereafter, the medium was collected (sample 1), changed to RPMI-1640 medium without FCS, supplemented with $1 \mu \mathrm{g}$ hydrocortisone hydrogen succinate $/ \mathrm{ml}$ and $20 \mu \mathrm{g}$ crystalline insulin/ $\mathrm{ml}$, and cultured for 72 hours. This procedure was repeated once (samples 2 and 3). After the last collection of culture fluid, the cells were harvested in $3 \mathrm{ml}$ of phosphate-buffered saline $(\mathrm{pH} 7.2)$ by their being scraped with a rubber policeman. The cell suspension was frozen and thawed twice and sonicated for 1 minute in the cold at an output power of 35 watts (Sonifier B 10; Branson Sonic Power Cio., Danbury, Conn.); it constituted sample 4 .

Several radioactive media were used. They consisted of a modified Eagle's nutrient mixture to which were added $1 \mu \mathrm{g}$ hydrocortisone hydrogen succinate $/ \mathrm{ml}, 20$ $\mu \mathrm{g}$ crystalline insulin $/ \mathrm{ml}, 121 \mu \mathrm{g}$ crystalline sodium penicillin $\mathrm{G} / \mathrm{ml}$, and $25 \mathrm{~mm} N$-2-hydroxyethylpiperazine- $N^{\prime}$-2-ethanesulfonic acid. To this basic composi- 
tion various labeled products were added: l) $0.5 \mu \mathrm{Ci} \mathrm{L}$ $\left[{ }^{14} \mathrm{C}\right] l y s i n e / \mathrm{ml}$ plus $0.5 \mu \mathrm{Ci} \mathrm{L}-\left[{ }^{14} \mathrm{C}\right]$ isoleucine $/ \mathrm{ml}(1,200-$ $1,270 \mathrm{mCi} / \mathrm{mmole})$; 2) $0.5 \mu \mathrm{Ci} \mathrm{L}-\left[{ }^{14} \mathrm{C}\right]$ arginine $/ \mathrm{ml}$ plus $0.5 \mu \mathrm{Ci} \mathrm{L}-\left[{ }^{14} \mathrm{C}\right]$ valine $\left./ \mathrm{ml}(>225 \mathrm{mCi} / \mathrm{mmole}) ; 3\right) 0.5 \mu \mathrm{Ci}$ [methyl-14 C]choline $/ \mathrm{ml}(40-60 \mathrm{mCi} / \mathrm{mmole})$; 4) $0.5 \mu \mathrm{Ci}$ D- $\left[{ }^{14} \mathrm{C}\right]$ galactosamine hydrochloride $/ \mathrm{ml}(>45 \mathrm{mCi} /$ mmole); and 5) $0.5 \mu \mathrm{Ci} \mathrm{D}-\left[{ }^{14} \mathrm{C}\right]$ glucosamine hydrochloride $/ \mathrm{ml}(>200 \mathrm{mCi} / \mathrm{mmole})$. All radiolabeled products were from Radiochemical Centre, Amersham, Buckinghamshire, England.

Several flasks of BT 20 cells were incubated only in medium RPMI-1640 without FCS. The cells were treated as the cells incubated in radiolabeled medium.

In several cultures, the radiolabeled medium and the RPMI-1640 medium were supplemented with 1) 50, 5, 0.5 , and $0.05 \mu \mathrm{g}$ ovine prolactin $/ \mathrm{ml}$ (NIH-P-Sl0; kindly supplied by the National Institute of Arthritis and Metabolic Diseases, Bethesda, Md.); 2) 5, 1, and 0.1 $\mu \mathrm{g}$ concanavalin $\mathrm{A} / \mathrm{ml}$ (Calbiochem, La Jolla, Calif.); 3) 10,5 , and $1 \mu l$ phytohemagglutinin $P / m l$ (Difco Laboratories, Detroit, Mich.); and 4) 10, 5, and $1 \mu \mathrm{l}$ pokeweed mitogen $/ \mathrm{ml}$ (Grand Island Biological Co., Grand Island, N.Y.).

Placentas, neoplastic and dysplastic human breast tissues, as well as liver, submandibular glands, intestine, spleen, and lungs from human fetus were cultured in roller tubes as described previously (34). After culture, all fluids were dialyzed against $0.005 \mathrm{M}(\mathrm{pH}$ 8.6) barbital buffer and lyophilized. Before lyophilization, the radioactivity of a $10-\mu$ l sample was counted on a filter paper in 2,5-diphenyloxazole-1,4-bis[2-(5phenyloxazolyl)]benzene toluol scintillation solution. The incorporation of the radioactive products into nondialyzable material was calculated by a comparison with the radioactivity of the medium before dialysis.

The lyophilized powders from cultures with radiolabeled medium were dissolved in $0.3 \mathrm{ml}$ of distilled water, and the solutions were analyzed by autoradiography of double diffusion and immunoelectrophoresis.

To $50 \mu$ l of several concentrated culture fluids from cultures with RPMI-1640 medium, $10 \mu \mathrm{l}$ of a solution containing $2.5 \mu \mathrm{Ci}$ of $\left[{ }^{59} \mathrm{Fe}\right]$ ferrous citrate $>4 \mathrm{mCi}$ $\mathrm{Fe} / \mathrm{mg}$; Eidgenössisches Institut für Reaktorforschung, Wurenlingen, Switzerland) was added. The solutions were analyzed by autoradiography of electrophoresis in agarose and immunoelectrophoresis.

Double diffusion in agar. - The micromethod was used in 2\% agar in $0.025 \mathrm{~m}$ barbital buffer, $\mathrm{pH} 8.2$.
Immunoelectrophoresis. - The micromethod of Scheidegger (35) was used with slight modifications for the LKB apparatus 6800 (LKB Products, Stockholm, Sweden). In double diffusion in agar and in immunoelectrophoresis, concentrated culture fluids were added with a carrier to the antigen wells. Various carriers and antisera were used according to the kind of protein to be demonstrated.

Electrophoresis in agarose.-Electrophoresis was made in agarose placed on a film of polyester (Readyfilm; Mullener, Spreitenbach, Switzerland) in 0.05 м barbital buffer ( $\mathrm{pH} 8.6$ ).

Polyacrylamide gel electrophoresis. - Culture fluids were analyzed by electrophoresis in a $6 \%$ polyacrylamide slab gel containing $0.1 \%$ SDS in $0.02 \mathrm{M}$ phosphate buffer ( $\mathrm{pH}$ 7.0). Several markers were also electrophoresed for an evaluation of the molecular weights: bovine serum albumin, ovalbumin (Pentex Inc., Kankakee, Ill.), and cytochrome c (Sigma Chemical Co., Saint Louis, Mo.). Each culture fluid was run twice on the gel. In one case the gel was dried and autoradiographed. In the other case it was cut along the length in 2-mm sections. Each fragment was digested overnight at $65^{\circ} \mathrm{C}$ in a $15 \%$ NCS (Amersham/Searle Corp., Arlington Heights, Ill.) solution in ammonia and then counted in scintillation liquid.

Autoradiography. - The immunoelectrophoresis and the double diffusion slides, the agarose electrophoresis slides, and dried SDS-polyacrylamide gel were placed in contact with photographic film (Kodak professional Royal Pan $400 \mathrm{ASA}$ ) for 14 or 42 days at room temperature.

Trichloroacetic acid precipitation.-Twenty microliters of several radioactive culture fluids were incubated with $25 \mu \mathrm{l}$ of normal human serum to which was added $125 \mu \mathrm{l}$ of $15 \%$ trichloroacetic acid. The precipitate formed was washed twice with $15 \%$ trichloroacetic acid by repeated centrifugation. The washed precipitate was solubilized in 50-100 $\mu \mathrm{l}$ of $2 \mathrm{~m} \mathrm{NaOH}$ and then transferred onto a filter paper. After drying, the filter paper was counted in scintillation liquid.

\section{RESULTS}

\section{Incorporation of ${ }^{14} \mathrm{C}$-Labeled Products Into Non- dialyzable Material}

BT 20 cells incorporated radiolabeled products into

TABLE 1.-Incorporation of ${ }^{14} \mathrm{C}$-labeled products into nondialyzable material ${ }^{a}$

\begin{tabular}{|c|c|c|c|c|c|}
\hline \multirow{2}{*}{ Experimental details } & \multicolumn{4}{|c|}{ Incorporation in sample ${ }^{b}$} & \multirow{2}{*}{ Total } \\
\hline & 1 & 2 & 3 & 4 & \\
\hline $\begin{array}{l}{\left[{ }^{14} \mathrm{C}\right] \text { lysine }+\left[{ }^{14} \mathrm{C}\right] \text { isoleucine, } 5 \text { expts, } 5 \text { flasks }} \\
{\left[{ }_{14} \mathrm{C}\right] \text { valine }+\left[{ }^{14} \mathrm{C}\right] \text { arginine, } 2 \text { expts, } 3 \text { flasks }} \\
{\left[{ }^{14} \mathrm{C}\right] \text { glucosamine, } 2 \text { expts, } 3 \text { flasks }} \\
{\left[{ }_{14} \mathrm{C}\right] \text { galactosamine, } 2 \text { expts, } 3 \text { flasks }} \\
{\left[{ }^{14} \mathrm{C}\right] \text { choline, } 1 \text { flask }}\end{array}$ & $\begin{array}{l}6.17 \pm 0.86 \\
4.03 \pm 0.92 \\
1.76 \pm 0.27 \\
1.16 \pm 0.03 \\
1.45\end{array}$ & $\begin{array}{l}9.67 \pm 2.83 \\
4.67 \pm 0.65 \\
1.13 \pm 0.31 \\
1.49 \pm 0.36 \\
4.48\end{array}$ & $\begin{array}{l}4.31 \pm 1.92 \\
4.43 \pm 0.88 \\
0.42 \pm 0.08 \\
0.88 \pm 0.10 \\
3.85\end{array}$ & $\begin{array}{l}48.82 \pm 14.21 \\
\mathrm{ND} \\
3.38 \pm 0.72 \\
\mathrm{ND} \\
44.85\end{array}$ & $\begin{array}{l}69 \pm 14.4 \\
\mathrm{ND}^{6.70 \pm 1.00} \\
\mathrm{ND}^{\mathrm{ND}}\end{array}$ \\
\hline
\end{tabular}

a The incorporation is expressed as the percentage of the initial radioactivity. The percentage is a mean of several experiments $\pm \mathrm{SD}$. $\mathrm{ND}=$ not done.

${ }_{b}$ Samples 1-3 correspond to culture fluids taken every $72 \mathrm{hr}$. Sample 4 is a harvest of the cultured cells after 9 days in culture. 
nondialyzable material in amounts varying according to the product used and to the period of culture (table 1). Precipitable by trichloroacetic acid was $84 \% \pm 3.6 \%$ of the radioactivity of the nondialyzable material.

With lysine and isoleucine used as ${ }^{14} \mathrm{C}$-labeled products, no significant difference in incorporation was seen between the BT 20 cells cultured in the radiolabeled medium with or without concanavalin A, phytohemagglutinin, pokeweed mitogen, or ovine prolactin.

Analysis of the culture fluids by autoradiography of electrophoresis in agarose revealed various bands, depending on the labeled products used and on the sampling time (fig. 1). Four bands were more anodal than albumin. Autoradiographs of SDS-polyacrylamide gel electrophoresis showed 14-19 bands varying from products that did not penetrate the gel to products having a molecular weight less than 12,300 daltons (cytochrome c). Several spots were common to the 4 samples; others were present in 1 or 2 samples only (fig. 2). These observations were particularly outstanding in the profiles of the graphs on radioactivity counts (text-fig. 1). Two peaks corresponding to a molecular weight of 55,000 and 28,000 daltons were present in all 4 samples. Two peaks with molecular weights of 17,000 and 9,000 daltons were found in the first 3 samples, a peak of 85,000 daltons was found in all samples with the exception of sample 3 , and a peak of 115,000 daltons was found in samples 1 and 2 .

\section{Characterization of Products}

The products synthesized by BT 20 cells were analyzed by autoradiography of double diffusion and immunoelectrophoresis slides. These products could be classified as serum proteins, milk proteins, membraneassociated proteins, and fetal proteins according to the antisera and carriers used.

\section{Serum Proteins}

In autoradiographs with normal human serum as carrier and with a swine antiserum polyvalent against serum proteins, 3-5 labeled lines were seen in culture fluid samples 1 and 2 from cells cultured with $\left[{ }^{14} \mathrm{C}\right] l y-$ sine and $\left[{ }^{14} \mathrm{C}\right]$ isoleucine. These lines had an $\alpha$ - and $\beta$ electrophoretic mobility in agar. No lines were visible in culture fluid samples 3 and 4 . When the culture fluids were analyzed with the same antiserum but without carrier, none had any visible labeled line.

For further characterization of these labeled lines, the culture fluids were analyzed with normal human serum as carrier against all the antisera specific for serum proteins mentioned in "Materials and Methods." Only culture fluid samples 1 and 2 gave labeled precipitation lines against 3 of the antisera used, namely, anti- $\boldsymbol{\beta}_{\mathbf{2}^{-}}$ glycoprotein I, anti- $\alpha_{2}$ HS-glycoprotein, and anti- $\alpha_{2}-$ lipoprotein (fig. 3c). No lines were visible in culture fluids from cells cultured with choline or glucosamine. No change in the above results was seen in culture fluids from cells cultured in the same medium supple- mented with concanavalin A, phytohemagglutinin, pokeweed mitogen, and prolactin.

\section{Milk Proteins}

No evidence was seen of labeled lines corresponding to free secretory component, lysozyme, casein, or lactalbumin. With rare culture fluids, the immunoprecipitation line corresponding to lactoferrin was labeled. However, this line was not visible when the culture fluid was used alone. Autoradiographs of electrophoresis in agarose and immunoelectrophoresis of culture fluids did not reveal lactoferrin.

\section{Membrane-Associated Proteins}

Three to 5 labeled lines were revealed in all 4 culture fluids with an antiserum specific for erythrocyte membrane (fig. 3a). A labeled line corresponding to glycophorin was seen only when a carrier was used with culture fluids from cells cultured with ${ }^{14} \mathrm{C}$-labeled amino acids. No labeled line corresponded to spectrin (fig. 4). However, with spectrin, glycophorin, or actin as carriers and antisera against spectrin and glycophorin, a labeled line not superposable on the precipitation line of the carrier was seen. With the system actin-antiactin, a labeled line at the limit of visibility corresponded to the precipitation line of the carrier. Whether the actin-labeled line was identical to that revealed by antispectrin and antiglycophorin sera could not be determined by double diffusion in agar.

A labled line corresponding to $\boldsymbol{\beta}_{2}$-microglobulin was seen with or without the use of a $\beta_{2}$-microglobulin carrier (fig. 3d). This labeled line was visible in samples 1 and 2 from cells cultured in a medium with $\left[{ }^{14} \mathrm{C}\right]$ lysine plus $\left[{ }^{14} \mathrm{C}\right]$ isoleucine or $\left[{ }^{14} \mathrm{C}\right]$ valine plus $\left[{ }^{14} \mathrm{C}\right]-$ arginine but not from cells cultured in a medium with $\left[{ }^{14} \mathrm{C}\right]$ glucosamine, $\left[{ }^{14} \mathrm{C}\right]$ galactosamine, or $\left[{ }^{14} \mathrm{C}\right]$ choline. In some of the samples 1 and 2 analyzed without carrier, a second line, parallel to the $\boldsymbol{\beta}_{2}$-microglobulin line and closer to the antigen well, was seen. This second labeled line was present in culture fluids from cells cultured in a medium with $\left[{ }^{14} \mathrm{C}\right]$ lysine, $\left[{ }^{14} \mathrm{C}\right]$ galactosamine, or in some cases with $\left[{ }^{14} \mathrm{C}\right]$ choline.

\section{Fetal Proteins}

A labeled line corresponding to CEA was seen only when CEA was used as carrier (figs. 5a, 5b). Synthesis of $\alpha_{1}$-fetoprotein, anodal isoferritin, or BOFA was not detectable.

In all culture fluids from BT 20 cells cultured with ${ }^{14} \mathrm{C}$-labeled amino acids and analyzed without a carrier, 1-3 radiolabeled lines were seen with 6 rabbit antisera against BT 20 cells. These lines corresponded to proteins that are also synthesized by human adult and fetal tissues (fig. 6). They were detected in all culture fluids from 5 placentas and from 17 fetal tissues originating from 6 different fetuses, in 9 culture fluids from 10 dysplastic breast tissues, and in 6 culture fluids from 11 breast carcinomas. Double diffusion in agar 

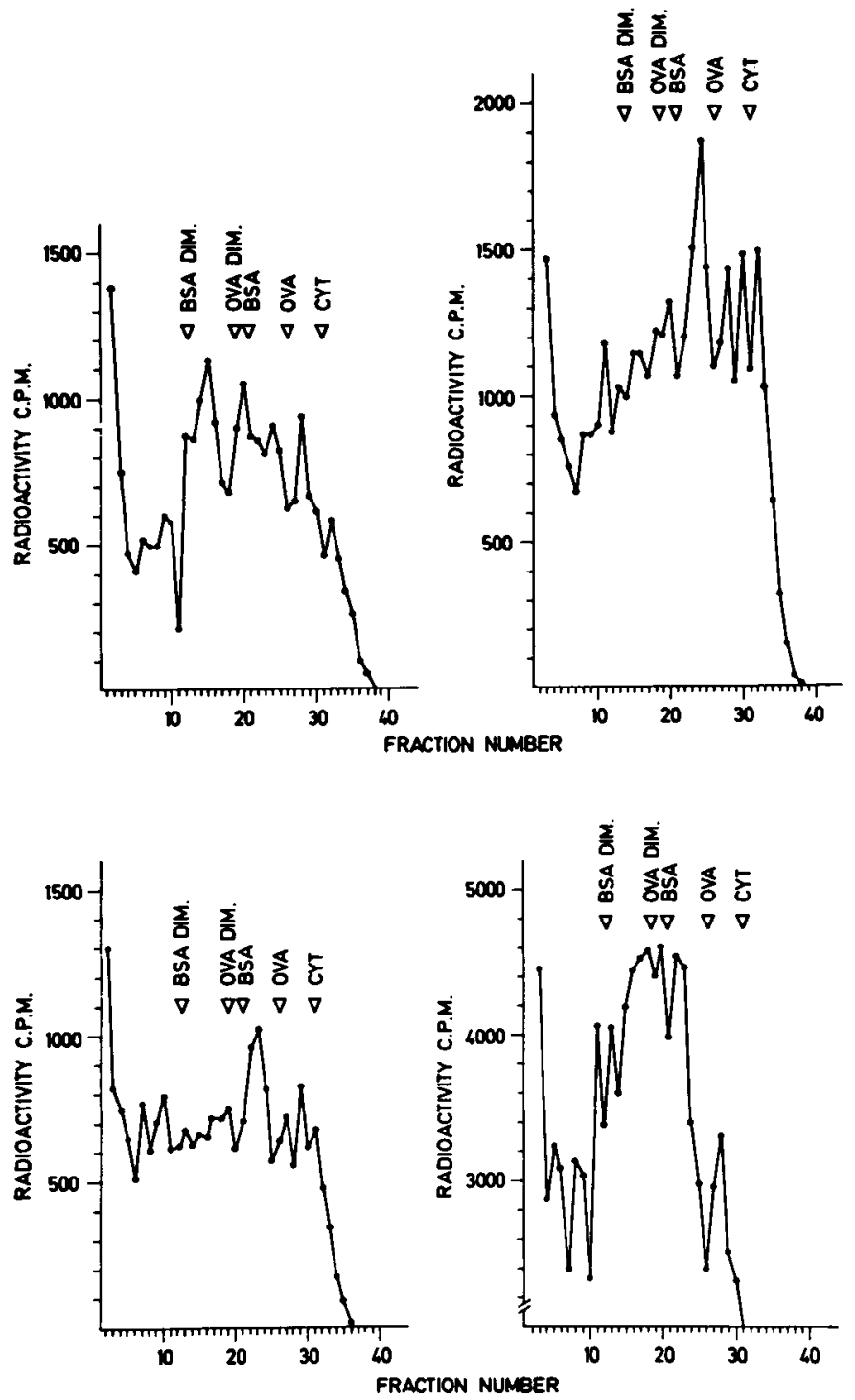

TEXT-Figure 1.-Curves of the radioactivity counts of SDS polyacrylamide gel electrophoresis. Ten microliters of concentrated culture fluid from BT 20 cells cultured with $\left[{ }^{14} \mathrm{C}\right]$ lysine and $\left[{ }^{44} \mathrm{C}\right]$ isoleucine was applied per gel. The positions of the markers are indicated. Slices were cut to $2 \mathrm{~mm}$ in length. Top left: sample 1 ; top right: sample 2; bottom left: sample 3; bottom right: sample 4 . OVA=ovalbumin; $\mathrm{BSA}=$ bovine serum albumin; $\mathrm{CYT}=$ cytochrome c; C.P.M.=counts per $\min$.

revealed a complete identity between these lines and the lines of culture fluids from BT 20 cells. The absorption of the anti-BT 20 antisera by FCS and double diffusion in the presence of FCS did not change the results. No labeled lines were visible in culture fluids from BT 20 cells cultured in a medium with $\left[{ }^{14} \mathrm{C}\right]$ choline, $\left[{ }^{14} \mathrm{C}\right]$ glucosamine, or $\left[{ }^{14} \mathrm{C}\right]$ galactosamine.

\section{DISCUSSION}

BT 20 cells incorporate various labeled products into nondialyzable materials that are released in culture over a 9-day period. The difference between the radioactivity in the nondialyzable materials and that in the precipitate obtained by trichloroacetic acid is probably due to the presence of small peptides. Human breast cancer cells have been reported to have concanavalin A receptors (36). We have, therefore, tried to stimulate the BT 20 cells with concanavalin A and other lectins. These attempts, as well as attempted stimulation with prolactin, were unsuccessful.

Several of the synthesized products have been identified. Of the 5 serum proteins, 3 have been characterized as $\beta_{2}$-glycoprotein I, $\alpha_{2} \mathrm{HS}$-glycoprotein, and $\alpha_{2}$-lipoprotein. We previously showed that the labeling of these precipitation lines is not due to a nonspecific fixation of radiolabeled material to the immune precipitate (34). These serum proteins are also synthesized by dysplastic and neoplastic human mammary tissues (34), and some of them probably correspond to glycoproteins whose concentrations have been found elevated in the sera of patients with breast carcinoma $(37,38)$. Although these serum proteins have been found in high concentrations in various diseases and are thought to be produced by the liver (39), their synthesis by $\mathrm{BT} 20$ cells necessitates a reconsideration of the role of the breast carcinoma itself in their production.

Milk proteins were not detected in any of the culture fluids from the different labeled media used. We did not take into account the rare labeling of lactoferrin, inasmuch as we did not find any synthesized products able to fix ${ }^{59} \mathrm{Fe}$.

Absence of synthesis of milk proteins could be due to several factors. Cells for the in vitro synthesis of these proteins possibly require a complex culture medium as noted by Flaxman (40) that does not correspond to our conditions of culture. Also, BT 20 cells may have lost some specific characteristics of differentiated mammary epithelium that have been kept in another cell line, MCF-7 (41). However, most probably the original carcinoma cells were unable to synthesize milk proteins. This had been shown to be so for many breast carcinomas. Casein was found by immunofluorescence in cells of 5 of 20 infiltrating ductal carcinomas of no special type (34). Monaco et al. (42) reported that only 8 of 47 breast cancer tumors were positive for casein and that none of the 7 breast cancer cells tested synthesized casein in vitro. Kleinberg (43) also showed that only 4 of 19 breast cancer tissues cultured in vitro synthesized lactalbumin. This absence of synthesis of milk proteins has also been demonstrated in cultures of rat and mouse mammary carcinoma cells (44). Together, these results suggest that most breast carcinoma cells in vitro and in vivo have lost their potential to synthesize milk proteins and that milk proteins are poor markers for most breast carcinomas.

Several proteins present on the erythrocyte membrane are synthesized by the BT 20 cells. One of them is glycophorin, the major protein of the erythrocyte membrane described by Marchesi et al. (45). With an antiserum specific for erythrocyte membrane, the radiolabeled lines are visible without the use of a carrier; however, the line revealed by an antiserum specific for glycophorin is labeled only when glycophorin is used as carrier. In contrast to the other carriers used in this study, glycophorin precipitated by its specific anti- 
serum captures unspecifically various labeled products. However, in these cases the radioactive line is just visible. The strong radiolabeled line of glycophorin with BT 20 culture fluids is in favor of a specific labeling. The necessity of using a carrier for the demonstration of glycophorin is perhaps due to the fact that the BT 20 cells synthesize only a part of the molecule of glycophorin as it exists in red blood cells. This molecule having only some of the antigenic determinants of glycophorin is probably not specific to the erythrocyte membrane but could be present on various other cells. This would further explain the immunologic cross-reaction between glycophorin and $a_{1}$, a human cell-surface antigen (46).

The in vitro synthesis of actin confirms the results obtained by immunofluorescence, which revealed the presence of actin in cells from several carcinomas and particularly from breast carcinomas $(47,48)$. The absence of spectrin synthesis is in accord with the results obtained by Hiller and Weber (49) with cultures of HeLa cells and fibroblasts. The samples of spectrin and glycophorin used are probably contaminated with small amounts of actin, and antisera specific for spectrin and one antiserum specific for glycophorin also reveal the antigenic determinants of actin. This could explain the fine labeled line obtained with these antisera when actin, spectrin, or glycophorin is used as carrier inasmuch as the labeled line is not superposable to the precipitation line. However, this hypothesis could not be proved by double diffusion in agar with the actin-antiactin system due to a labeling at the limit of visibility and the difficulty of having an adequate concentration of all the antisera and carriers on the same slide.

BT 20 cells synthesize $\beta_{2}$-microglobulin as do many other tumor cell lines (50). However, the detection of a second labeled line with an antiserum specific for $\boldsymbol{\beta}_{2^{-}}$ microglobulin warrants further study. The position of this line near the antigen well and its curvature suggest that the line corresponds to a product heavier than $\beta_{2-}$ microglobulin. Whereas the usual line of $\beta_{2}$-microglobulin is labeled only with ${ }^{14} \mathrm{C}$-labeled amino acids, the supplementary line is labeled also with $\left[{ }^{14} \mathrm{C}\right] \mathrm{glu}$ cosamine. These two observations taken together suggest that the supplementary line corresponds to $\boldsymbol{\beta}_{2}$ microglobulin associated with a glycoprotein which could be a transplantation antigen or a tumor-specific antigen. Thomson et al. (16) reported that antigenic tumor material from human breast cancer was associated with $\beta_{2}$-microglobulin, and Nakamuro et al. (51) demonstrated $\boldsymbol{\beta}_{2}$-microglobulin in an unbound state and bound to HLA in several human cell lines.

The BT 20 cells synthesize 4 fetal proteins, one of which is CEA. However, it is not possible to specify whether this protein is the CEA originally described by Gold and Freedman (52) or a breast carcinoma membrane-associated antigen that shares antigenic determinants with CEA as reported by Kuo et al. (11). Three other fetal proteins are detected by the anti-BT 20 cell antisera. These antisera detect only these proteins and no proteins specific to the BT 20 cells. Some or all of these proteins could correspond to products synthesized by mycoplasma that contaminated some cultures. However, this does not seem to be the case inasmuch as the anti-BT 20 antisera show the same radiolabeled lines when tested with either the contaminated culture fluids or the mycoplasma-free culture fluids. Moreover, the same labeled lines are obtained with the use of antisera against BT 20 cells with culture fluids from various human tissues cultured for 48 or 72 hours only, in which there is little probability of a mycoplasma contamination.

We have not evaluated the relationship between the 3 other fetal proteins and most of the numerous fetal proteins described to date $(32,53-59)$. However, we can prove that these fetoproteins are neither $\alpha_{1}$-fetoprotein, BOFA, or ferritin nor components due to cultivation in medium containing FCS (60). The cultures were maintained for 9 days without FCS, with two changes of medium, and desorption of FCS occurs at 3 days (61). Also, the antisera specific for BT 20 cells, which reveal these fetal proteins, do not precipitate any constituents of FCS. Moreover, both absorption of the anti-BT 20 cells antisera by FCS and double diffusion in the presence of FCS did not change the results.

Both BT 20 cells as well as neoplastic and dysplastic human mammary tissues synthesize these fetal antigens in relatively large amounts, as demonstrated by the intensity of the radiolabeled lines. These proteins can be classified in the group of oncofetal-associated antigens described by Alexander (62). The synthesis of these oncofetal-associated antigens could be due to a derepression caused either by tumor transformation of the cells or by the tissue culture conditions, inasmuch as Parker et al. (63) have demonstrated that normal tissues can express new fetal antigens in vitro. Thus the in vivo importance of these oncofetal antigens remains to be determined.

The results obtained are promising in that many products which are probably important as characteristics of the breast carcinoma cells are synthesized as soluble antigens in vitro by BT 20 cells. Isolation and purification of these products are in progress in our laboratory; the preparation of antisera against these products could lead to their identification in various tissues.

\section{REFERENCES}

(1) Estes NC, Morse PA, Humphrey LJ: Antibody studies of sera from patients with breast cancer. Surg Forum 25:121-123, 1974

(2) Gorsky Y, VAnky F, Sultrzeant D: Isolation from patients with breast cancer of antibodies specific for antigens associated with breast cancer and other malignant diseases. Proc Natl Acad Sci USA 73:2101-2105, 1976

(3) Priori ES, Seman G, Dmochowski HS, et al: Immunofluoresence studies on sera of patients with breast carcinoma. Cancer 28:1462-1471, 1971

(4) Sinkovics JG, Rreves WJ, Cabiness JR: Cell- and antibodymediated immune reactions of patients to cultured cells of breast carcinoma. J Natl Cancer Inst 48:1145-1147, 1972

(5) Delia Porta G, Canevari S, Fossati G: Immune responses to tumour and embryo cells in patients with mammary carcinoma. Br J Cancer 28 (suppl I):103-107, 1973 
(6) Baldwin RW, Embleton MJ, Jones JS, et al: Cell-mediated and humoral immune reactions to human tumours. Int J Cancer 12:73-83, 1973

(7) Fossati G, Canevari S, Della Porta G, et al: Cellular immunity to human breast carcinoma. Int J Cancer 10:391-396, 1972

(8) Cochran AJ, Spilg WG, Mackie RM, et al: Postoperative depression of tumour-directed cell-mediated immunity in patients with malignant disease. $\mathrm{Br}$ Med J 4:67-70, 1972

(9) MCCOY JL, JERome LF, ANDERSON C, et al: Leukocyte migration inhibition by soluble extracts of MCF-7 tissue culture cell line derived from breast carcinoma. J Natl Cancer Inst 57: $1045-1049,1976$

(10) MCCOY JL, JERome LF, DeAn JH, et al: Inhibition of leukocyte migration by tumor-associated antigens in soluble extracts of human breast carcinoma. J Natl Cancer Inst 53:1117. 1974

(11) Kuo T, Rosai J. Tillack TW: Immunological studies of membrane glycoproteins isolated from human breast carcinomas. Int J Cancer 12:532-542, 1973

(12) Taylor G, Onili JL: Tumour specific T-like antigen of human breast carcinoma. Br J Cancer 24:447-453, 1970

(13) Gentile JM, Flicisinger JT: Isolation of a tumor-specific antigen from adenocarcinoma of the breast. Surg Gynecol Obstet $135: 69-73, \quad 1972$

(14) Zacihrau RE, Black MM, Dion AS, et al: Prognostically significant protein components of human breast cancer tissues. Cancer Res 36:3143-3146, 1976

(15) BARTORELL A, AC:CiNNI R: Immunological and radioimmunological studies of membrane antigen(s) from human breast carcinomas and non-tumoral breast tissues. I. Experientia 33: 85-87, 1977

(16) Thomson DM, Gold P, Freedman SO, et al: The isolation and characterization of tumor-specific antigens of rodent and human tumors. Cancer Res 36:3518-3525, 1976

(17) Poskite PK. Poskiti TR, Wallack JH: Release in culture medium of membrane-associated, tumor-specific antigen by B-16 melanoma cells. Proc Soc Exp Biol Med 152:76-80, 1976

(18) BYSTRYN JC: Release of tumor-associated antigens by murine melanoma cells. J Immunol 116:1302-1310, 1976

(19) HIC:KOK DF, MILLER L: Evidence for tumor-specific antigens in filtered tissue culture media from human cancer cells. In Vitro 10:157-166, 1974

(20) Singi I, TSang; KY, Blakemore WS: Isolation and partial purification of plasma membrane-associated antigens from human osteosarcoma (TE-85) cells in tissue culture. Cancer Res 36: 4130-4136, 1976

(21) Grimm EA, Silver HK, Roth JA, et al: Detection of tumorassociated antigen in human melanoma cell line supernatants. Int J Cancer 17:559-564, 1976

(22) Stuhlmiller GM, Seiciler HF: Enzymatic susceptibility and spontaneous release of human melanoma tumor-associated antigens. J Natl Cancer Inst 58:215-221, 1977

(23) Lasfarciues EY, Ozzello L: Cultivation of human breast carcinomas. J Natl Cancer Inst 21:1131-1147, 1958

(24) Otzello L, SORDAT B, MERENDA C, et al: Transplantation of a human mammary carcinoma cell line (BT 20) into nude mice. J Natl Cancer Inst 52:1669-1672, 1974

(25) Brandtzakc; P: Human secretory component. I. Purification of free secretory component from colostrum. Scand J Immunol 3:579-588, 1974

(26) Querinjean P, Masson PL, Heremans JF: Molecular weight, single-chain structure and aminoacid composition of human lactoferrin. Eur J Biochem 20:420-425, 1971

(27) Kaplanas RI, ANTANaricinyns AI: The isolation and purification of $\alpha$-lactalbumin, a component of lactose synthetase. Biochemistry 40:493-495, 1975

(28) Naciasawa T, Ryoki T, Kryosawa I, et al: Studies on human casein. I. Fractionation of human casein by diethylaminoethyl cellulose column chromatography. Arch Biochem Biophys 121:502-507, 1967

(29) Tillack TW, Scott RE, Marchesi VT: The structure of erythrocyte membrane studied by freeze-etching. II. Localization of receptors for PHA and influenza virus to the intra- membranous particles. J Exp Med 135:1209-1227, 1972

(30) Bron C, Gallagher G: Immunochemical studies of human red cell membrane proteins excreted in normal urine. Immu. nochemistry 11:409-415, 1974

(31) BERTHOUD D, BRON C: Antigenicity of human glycophorin constituents. Experientia 32:765, 1976

(32) FrITSCHÉ R, MAC:H J: Identification of a new oncofoetal antigen associated with several types of human carcinomas. Nature 258:794-737, 1975

(33) Chaponnier C, Kohler L, Gabbiani G: Fixation of human anti-actin autoantibodies on skeletal muscle fibres. Clin Exp Immunol 27:278-284, 1977

(34) Hurlimann J, LichaA M, Ozzello L: In vitro synthesis of immunoglobulins and other proteins by dysplastic and neoplastic human mammary tissues. Cancer Res 36:1284-1292. 1976

(35) Sciheidegger JJ: Une micromethode de l'immunoelectrophorèse. Int Arch Allergy Appl Immunol 7:103-110, 1955

(36) Matoska J, Siracky J: Concanavalin A receptors on the surfaces of human breast cancer cells in organ culture. J Natl Cancer Inst 58:21-28, 1977

(37) MACBeTh RA, BekeSI JG: Plasma glycoproteins in various disease states including carcinoma. Cancer Res 22:1170-1176, 1962

(38) Rosato FE, Seltzer MH: Serum protein-bound fucose and carcinoma of the female breast. Am J Surg 118:61-64, 1969

(39) Roberts JG, Keyser JW, Baum M: Serum a-1-acid glycoptotein as an index of dissemination in breast cancer. Br J Surg 62:816-819, 1975

(40) Flaxman A: In vitro studies of the normal mammary gland. J Invest Dermatol 63:48-57, 1974

(41) ROSE HN, MCGRATH CM: $\alpha$-Lactalbumin production in human mammary carcinoma. Science 190:673-675, 1975

(42) Monaco ME, Brouzert DA, Tormey DC, et al: Casein production by human breast cancer. Cancer Res 37:749-754, 1977

(43) KLEINBERG; DL: Human $\alpha$-lactalbumin: Measurement in serum and in breast cancer organ cultures by radio immunoassay. Science 190:276-278, 1975

(44) TuRKINGTON RW, RIDDle M: Expression of differentiated function by mammary carcinoma cells in vitro. Cancer Res 30: 127-132, 1970

(45) Marchesi VT, Tillack TW, Jackson RL, et al: Chemical characterization and surface orientation of the major glycoprotein of the human erythrocyte membrane. Proc Natl Acad Sci USA 69:1445-1449, 1972

(46) MoOre EE, Jones C, Puck TT: Cell surface antigens. IV. Immunological correspondence between glycophorin and the $a_{1}$ human cell surface antigen. Cytogenet Cell Genet 17:89-97, 1976

(47) Gabbiani G, Trencher P. Holborow EJ: Increase of contractile proteins in human cancer cells. Lancet 2:796-797, 1975

(48) Gabbiani G, Csank-Brassert J, Schneeberger JC, et al: Contractile proteins in human cancer cells. Am J Pathol 83:457474, 1976

(49) Hiller G, Weber K: Spectrin is absent in various tissue culture cells. Nature 266:181-183, 1977

(50) Nilsson K, Evrin PE, Berggard I, et al: Involvement of lymphoid and non-lymphoid cells in the production of $\boldsymbol{\beta}_{2}$ microglobulin-a homologue of the constant domains of lgG. Nature [New Biol] 244:44-45, 1973

(51) Nakamuro K, Tanigaki N, Pressman D: Common antigenic structures of HLA antigens. VII. Selective combination binding of $\beta_{2}$-microglobulin with HLA large component in cultured human cell lines. Immunology 32:139-150, 1977

(52) Gold P, Freedman SO: Demonstration of tumor-specific antigens in human colonic carcinomata by immunological and absorption techniques. J Exp Med 121:439-459, 1965

(53) Edynack EM, Lardis MP, VRana M: Antigenic changes in human breast neoplasia. Cancer 28:1457-1461, 1971

(54) Edynack EM, Old LJ, Vrana $M$, et al: A fetal antigen associated with human neoplasia. N Engl J Med 286:1178-1183, 1972

(55) HÄKKINEN I, VIIKARI S: Occurrence of fetal sulphoglycoprotein antigen in the gastric juice of patients with gastric diseases. 
Ann Surg 169:277-281, 1969

(56) Klavins JV, Mesa-Tejada R, Weiss M: Human carcinoma antigens cross reacting with anti-embryonic antibodies. Nature [New Biol] 234:153-154, 1971

(57) Takahashi A, Yacihi A, Anzai T, et al: Presence of a unique serum protein in sera obtained from patients with neoplastic diseases and in embryonic and neonatal sera. Clin Chim Acta $17: 5-12, \quad 1967$

(58) Harris R, Vizi D, Tond R, et al: Detection of human leukaemia associated antigens in leukaemic serum and normal embryos. Nature 233:556-557, 1971

(59) TataRinov YS, Kalashnikov VV: New human embryonic antigen and its presence in some adenocarcinomas. Nature 265:
638-639, 1977

(60) IRIE RF, IRIF K, MORToN DL: Natural antibody in human serum to a neoantigen in human cultured cells grown in fetal bovine serum. J Natl Cancer Inst 52:1051-1058, 1974

(61) Kr.Rbei. RS, BlakeSlete D: Rapid adsorption of a fetal calf serum component by mammalian cells in culture. A potential source of artifacts in studies of antisera to cell-specific antigens. Immunology 31:881-891, 1976

(62) Al.t.Xinder P: Foetal "antigens" in cancer. Nature 235:137-140, 1972

(63) Parker GA, Hyate C, Rosenbrer: SA: Normal adult murine cells in tissue culture express fetal antigens. Transplantation 23:161-163, 1977
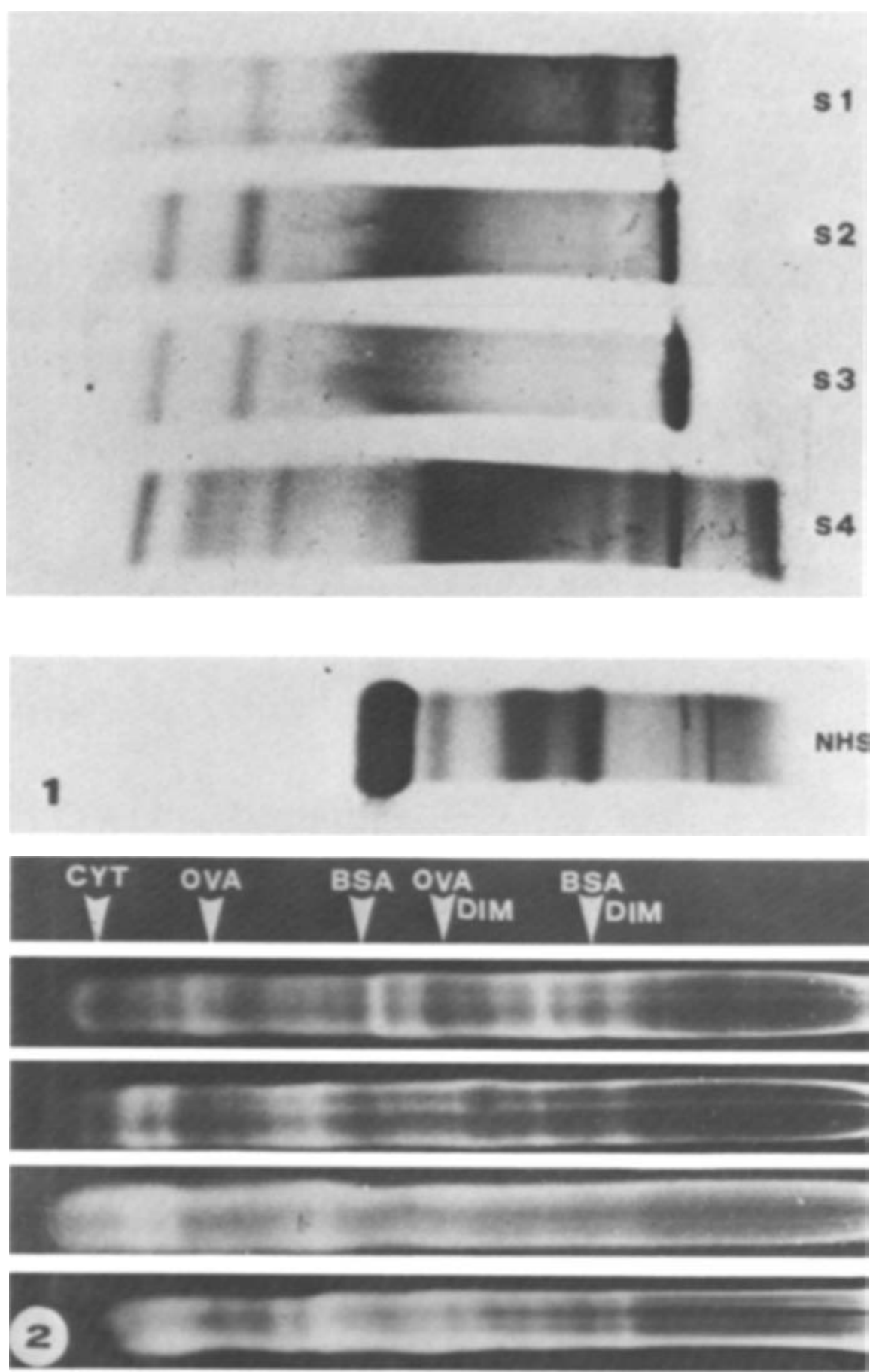

FIGi'Rf: 1.-Autoradiographs of agarose electrophoresis of culture fluids from BT 20 cells cultured with $\left[{ }^{14} \mathrm{C}\right]$ lysine plus $\left[{ }^{14} \mathrm{C}\right.$; $]$ isoleucine, samples 1-4 (S1-S4). At bottom, electrophoresis of normal human serum (NHS) as reference for electrophoretic mobilities.

FIGire 2.-Autoradiographs of SDS polyacrylamide gel electrophoresis of culcure fluids from BT 20 cells cultured with [ ${ }^{14}(:] l y$ sine plus $\left[{ }^{14} \mathrm{C}\right]$ isoleucine. From top to bottom: samples 1-4. Markers are indicated C:Y T=cytochrome $\mathrm{c}$; OVA=ovalbumin; $\mathrm{BS} A=$ bovine serum albumin; $\mathrm{DIM}=$ dimer . 

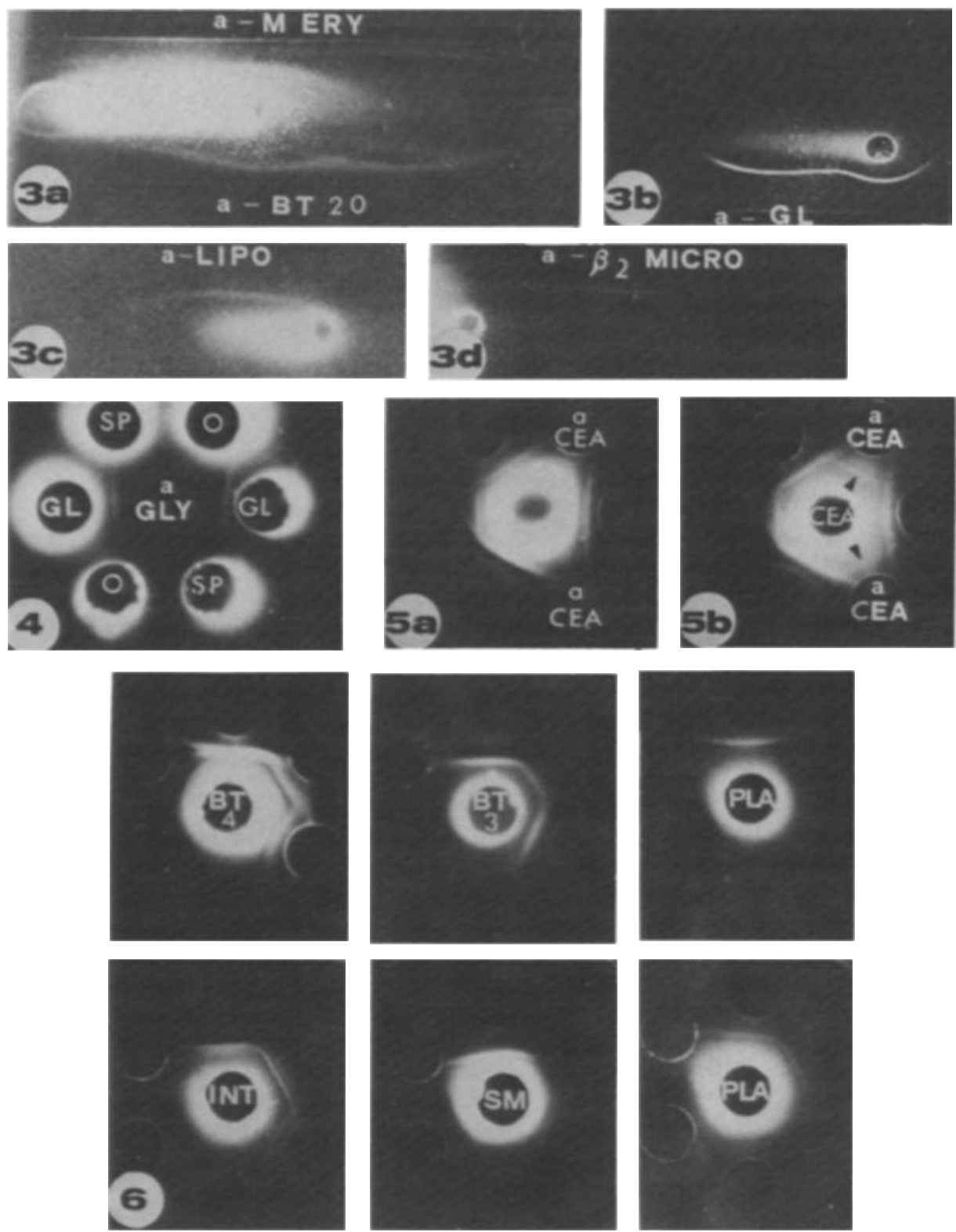

FIGURE 3.-Autoradiographs of immunoelectrophoresis of culture fluids from BT 20 cells. a) No carrier, antierythrocyte membrane (a-M ERY) and anti-BT 20 cell serum (a-BT 20). b) Glycophorin as carrier and antiglycophorin serum (a-GL). c) Human serum as carrier and anti- $\alpha_{2}$ lipoprotein serum (a-LIPO). d) $\beta_{2}$-microglobulin as carrier and anti- $\beta_{2}$-microglobulin serum (a- $\beta_{2}$ MICRO). Anode is on left.

FicitRE 4.-Autoradiograph of double diffusion in agar. In center well, antiserum specific for glycophorin (a-GLY); in peripheral wells, culture fluids from 2 different cultures of BT 20 cells alone (O) or with glycophorin (GL) or spectrin (SP) as carriers.

FIGURE 5. - Autoradiographs of double diffusion in agar. In center well, culture fluid from BT 20 cells alone (fig. 5a) or with CEA as carrier (fig. 5b). In peripheral wells, anti-BT 20 cell sera and anti-CEA sera (a CEA). Labeled line of CEA is visible with CEA as carrier (arrowheads).

Ficiurt 6.-Autoradiographs of double diffusion in agar. Peripheral wells contain 3 different anti-BT 20 cell sera. Center well contains samples 3 and 4 from BT 20 cells (BT 3 and BT 4), from 2 different placentas (PLA), and from fetal intestine (INT) and fetal submandibular gland (SM). 